\title{
A representação da crise do Período Especial em Cuba na obra Trilogia suja de Havana
}

\section{The representation of the Special Period crisis in Cuba in the book Dirty Havana Trilogy}

Giselle Cristina dos Anjos Santos ${ }^{1}$

\begin{abstract}
Resumo
A sociedade cubana vivenciou inúmeras transformações na esfera social, a partir da revolução socialista de 1959. Com o desaparecimento da União Soviética, seu principal aliado político e econômico, a sociedade cubana adentrou em uma grande crise econômica no início da década de 1990, denominada como "Período Especial". Esse processo evidenciou o reaparecimento de antigos fenômenos sociais considerados extintos, como o fenômeno da prostituição (jineterismo). Este artigo busca discutir as representações sociais construídas sobre a crise econômica e os diferentes atores sociais inseridos nesse contexto, por meio da obra Trilogia suja de Havana (1998) de Pedro Juan Gutiérrez.
\end{abstract}

Palavras-chave: Cuba; representação; crise; Pedro Juan Gutiérrez; período especial.

\begin{abstract}
Cuban society has experienced many changes in the social sphere, from the socialist revolution of 1959. With the demise of the Soviet Union, its main political and economic ally, Cuban society has entered into a major economic crisis in the early 1990s, known as "special Period." This process showed the reappearance of old social phenomena considered extinct, as the phenomenon of prostitution (jineterismo). This article seeks to discuss the social representations constructed on the economic crisis and the different social actors inserted in this context, through the work Dirty Havana Trilogy (1998) by Pedro Juan Gutiérrez.
\end{abstract}

Keywords: Cuba; representation; crisis; Pedro Juan Gutiérrez; special period.

Artigo recebido em: 30/08/2014

Artigo aprovado para publicação em: 26/11/2014

\footnotetext{
${ }^{1}$ Graduada em História pela Pontifícia Universidade Católica de São Paulo (PUC-SP). Mestre em Estudos Interdisciplinares sobre Mulheres, Gênero e Feminismo da Universidade Federal da Bahia (PPGNEIM - UFBA), com a pesquisa Mulheres negras em Cuba: representações sociais em tempos de crise (1990-2012), financiada pela Capes. Autora da publicação Somos todas rainhas (Associação Frida Kahlo e Articulação Política de Juventudes Negras, 2011), sobre a história das mulheres negras no Brasil. E-mail: santos.gisellea@gmail.com .
}

\section{GANPHLAC}

Revista Eletrônica da ANPHLAC, ISSN 1679-1061, N. 17, p. 139-168, jul./dez. 2014.

http://revista.anphlac.org.br/ 
Este artigo possui como objetivo discutir as representações sociais existentes sobre a crise econômica do Período Especial, vigente na sociedade cubana a partir dos anos 1990, na obra Trilogia suja de Havana (1998), de Pedro Juan Gutierrez.

Esta análise se constrói em diálogo com a perspectiva da história cultural. Para Roger Chartier (1988, p. 16-17), a história cultural "tem por principal objeto identificar o modo como em diferentes lugares e momentos uma determinada realidade social é construída, pensada e dada a ler”.

O uso da literatura como documento analítico caracteriza-se como um dos traços marcantes da nova história cultural. Ao analisar o tempo da escrita, historiadoras e historiadores podem vir a interpretar indícios sobre o local social e o contexto histórico onde a obra em questão foi produzida. Assim, o texto literário efetiva-se como um importante veículo para resgatar as motivações, sensibilidades e representações de uma época, por meio da narrativa construída por seus autores (PESAVENTO, 2008).

Segundo Sandra Pesavento (2008), a utilização desse tipo de fonte de análise desloca a atenção do(a) historiador(a) da veracidade para a verossimilhança e, dessa forma, coloca em questão os efeitos do real e de verdade que uma determinada narrativa histórica pode produzir.

No contexto cubano, a literatura e a produção cultural, de modo geral, constituem-se como importantes ferramentas para a reflexão sobre os fenômenos sociais. Segundo o historiador Abel Sierra (2006, p. 16),

a crítica social en Cuba es realizado fundamentalmente a través de la literatura, el teatro y el cine, como si el modo artístico o ficcional conformara sub productos expresivos de una realidad que necesariamente se altera o distorsiona.

Assim, a produção cultural, e mais precisamente a literatura, efetiva-se como fonte de análise privilegiada para investigar uma sociedade onde existem restrições estruturais para a construção de discursos plurais, dissonantes e discordantes.

Segundo o historiador Rafael Rojas (2009, p. 12) escritores, artistas e acadêmicos que se oponham publicamente aos direcionamentos políticos do governo,

\section{GANPHLAC}

Revista Eletrônica da ANPHLAC, ISSN 1679-1061, N. 17, p. 139-168, jul./dez. 2014. http://revista.anphlac.org.br/ 
dentro da ilha ou desde o exílio, são catalogados como intelectuais "não-cubanos" e "anti-cubanos". Ou seja, esses intelectuais passam a ser rotulados como inimigos da sociedade como um todo, sem abertura para a divulgação e o debate público de seu trabalho. Rojas considera que esse processo conforma uma concepção excludente da cultura nacional, instituindo um modelo de ilustração e cidadania sitiadas.

A própria Trilogia suja de Havana, escrita por Pedro Juan Gutiérrez - a obra mais expressiva desse autor, editada em vinte países -, nunca foi publicada em Cuba, assim como a maioria dos livros de sua autoria. ${ }^{2}$ Gutiérrez, classificado como um dos principais escritores latino-americanos contemporâneos, ${ }^{3}$ expõe na Trilogia os múltiplos conflitos presentes na vida cotidiana do personagem homônimo Pedro Juan, durante alguns dos anos mais difíceis da crise econômica (1994-1997). O livro explicita temas tabus e oficialmente silenciados pelo governo, como a prostituição, a violência, o racismo, a corrupção, a homossexualidade, a imigração, o suicídio, a repressão e o "mercado negro". 4

É relevante analisar as representações acerca da crise na sociedade cubana por meio dessa obra, pois Gutiérrez apropriou-se de inúmeros códigos discursivos, como os ditados populares e expressões correntes nesse cenário, para compor sua obra. A narrativa expõe de modo visceral discursos, representações, tensões e conflitos presentes no contexto do Período Especial (MARQUÉZ, 2007; SARABIA, 2012).

Assumo como referência para análise da fonte literária a categoria de representações sociais formulada por Chartier (1988), que a entende como figuras

\footnotetext{
${ }^{2}$ Pedro Juan Gutiérrez é autor de dez livros em prosa, oito livros de poesia e dois livros de não ficção. As obras do autor publicadas no Brasil são: GUTIÉRREZ, Pedro Juan. Animal tropical. São Paulo: Companhia das Letras, 2002. ___. Nosso GG em Havana. Rio de Janeiro: Alfaguara, 2008. insaciável Homem-Aranha. São Paulo: Companhia das Letras, 2004. Memórias do filho do sorveteiro. São Paulo: Companhia das Letras, 2005. O ninho da serpente: Paulo: Companhia das Letras, 2001. Além do livro Trilogia suja de Havana, publicado por duas editoras diferentes.

${ }^{3}$ Rojas (2009, p. 214) discute a persistência de ausências expressivas para a construção do debate intelectual na sociedade cubana durante o contexto revolucionário, devido à anulação e ao silêncio sobre importantes obras, escritas por autores no exílio, e até mesmo residentes na ilha, que nunca foram publicadas em Cuba. Esse autor elabora uma lista com os 70 títulos (agrupados em sete gêneros literários) mais expressivos dentro de sua perspectiva, de escritores cubanos publicados no exterior que ainda não foram publicados na ilha. A Trilogia suja de Havana, de Gutiérrez, encontra-se entre os livros citados nessa lista, compondo o grupo de livros do gênero de prosa e conto.

${ }^{4}$ Apesar de não concordar com o termo "mercado negro", por considerá-lo ofensivo ao associar o termo "negro" a práticas sociais ilícitas, irei utilizá-lo de acordo com a literatura que discute o mercado de vendas de produtos paralelos na sociedade cubana.
}

\section{GANPHLAC}

Revista Eletrônica da ANPHLAC, ISSN 1679-1061, N. 17, p. 139-168, jul./dez. 2014. http://revista.anphlac.org.br/ 
graças às quais o presente pode adquirir sentido, ao permitir ver uma coisa ausente. As representações do mundo social são construídas por meio de disputas de poder e de dominação que almejam constituir a universalidade de um diagnóstico fundado na razão, mas são sempre formulados de acordo com os interesses dos grupos que as forjam.

Ao buscar relacionar a construção discursiva do social e a construção social dos discursos (CHARTIER, 2002, p. 97), almejo refletir, por meio do discurso ${ }^{5}$ de Gutiérrez, sobre as representações vigentes no imaginário social sobre a crise econômica e os diferentes atores inseridos nesse contexto.

\section{“Período Especial em tempos de paz": crise econômica e crise de valores}

A revolução cubana, exitosa em $1^{\circ}$ de janeiro de 1959, representa um marco na história recente da América Latina e a construção de novos traços na história dessa sociedade. Com a derrocada do governo ditador de Fulgêncio Batista (1952-1958), o novo governo revolucionário assumiu o poder, constituído por uma articulação política com diferentes orientações, a partir do direcionamento nacionalista e anti-imperialista. Somente no ano de 1961 a revolução assumiu o caráter socialista.

A ruptura de relações com o governo dos Estados Unidos, que promoveu uma política de embargo econômico contra Cuba, favoreceu a constituição de um estreito vínculo político entre a ilha e a antiga União das Repúblicas Socialistas Soviéticas (URSS). Essa aliança refletiu-se especialmente por meio de relações econômicas, apoio militar, bem como no direcionamento da concepção política do Estado cubano.

Antes da revolução, existiam inúmeros problemas sociais que afligiam a população, como a pobreza e a desigualdade social, o analfabetismo (40\% da população não era letrada), a problemática da prostituição ${ }^{6}$ (estima-se que 100 mil mulheres se

\footnotetext{
5 O termo discurso é compreendido aqui dentro da acepção proposta pelo filósofo Michel Foucault (1999), como um arquivo de imagens e afirmações que forjam uma linguagem comum, possibilitando representar sentidos e conhecimentos sobre um determinado tema. Para Pesavento (1995, p. 18), “O discurso e a imagem, mais do que meros reflexos estáticos da realidade social, podem vir a ser instrumentos de constituição de poder e transformação da realidade".

${ }^{6}$ Desde o final do século XIX, a ilha de Cuba passou a ser conhecida internacionalmente como "burdel del Caribe", e posteriormente, em meados da década de 1910, passou a ser chamada de "bordel norte-
}

\section{CANPHLAC}

Revista Eletrônica da ANPHLAC, ISSN 1679-1061, N. 17, p. 139-168, jul./dez. 2014. http://revista.anphlac.org.br/ 
prostituíam), entre outras questões. O governo revolucionário priorizou investimentos, especialmente, nas áreas de educação, saúde e emprego, considerados setores fundamentais para o desenvolvimento social, o que propiciou transformações sociais significativas (AYERBE, 2004).

Os primeiros anos da revolução foram momentos de grande efervescência política e participação popular, quando toda a população foi convocada a atuar nas tareas de la revolución, por meio da participação nas organizações de massas e do desenvolvimento do trabalho voluntário. ${ }^{7}$

Porém, as metas de transformação política não se restringiam apenas às mudanças no âmbito material. Ernesto Che Guevara (2005), importante líder da revolução, foi o principal impulsionador da edificação do ideal do "homem novo" em Cuba. ${ }^{8}$ Esse modelo discursivo representava a transformação do indivíduo de pensamento individualista, característico da sociedade capitalista, para a edificação de homens e mulheres com consciência e práticas implicadas com as questões coletivas da nova sociedade socialista. ${ }^{9}$

americano". Segundo Elizalde (1996), em 1959, quando a população era de 6 milhões de pessoas, estimase que 100 mil mulheres se dedicavam ao oficio da prostituição na ilha. O governo revolucionário definiu o fim da prostituição como uma de suas prioridades. Foram fechados todos os bordéis, foi oferecida qualificação profissional para as mulheres que desenvolviam esse ofício nas escolas de superação geridas pela Federação de Mulheres Cubanas, além da oferta de atenção aos seus filhos. O governo realizou o "internamiento en granjas agrícolas y medidas carcelarias para las pocas que aún continuaban ejerciendo" (DÍAZ; GONZÁLEZ, 1997, p. 169) tal função. Desta maneira, a prostituição foi declarada oficialmente extinta em 1965; no entanto, ela não deixou de existir no contexto revolucionário, ainda que de forma reminiscente.

${ }^{7} \mathrm{O}$ trabalho voluntário era incentivado como atividade fundamental para a demonstração do apoio à revolução. Além da campanha pela alfabetização em 1960, que reuniu 100 mil professores voluntários, ocorreu outra mobilização expressiva em 1970 para a produção de "Dez milhões de toneladas" de cana de açúcar que seriam exportados para a URSS. Mas, apesar do grande empenho da população, a meta recorde de produção não foi atingida. Para a socióloga Velia Bobes (1999), a participação de grandes quantidades de cubanos atuando nessas tarefas foi importante para construir a imagem do povo como os protagonistas das transformações que ocorreram no país.

${ }^{8} \mathrm{O}$ ideal do homem novo foi esboçado por diferentes pensadores socialistas, como Marx, Engels, Lenin e Mao Tsé-tung. A construção da sociedade socialista, o alcance do comunismo e a consolidação do homem novo seriam forjados através das bases da moral comunista. Para Lenin, essa concepção cumpriria funções específicas na edificação do Estado soviético, pois, a moral comunista não poderia ser um conceito transcendente ou dissociado da humanidade, mas uma perspectiva subordinada integralmente à luta de classes (PERICÁS, 1998, p. 101).

${ }^{9}$ As principais virtudes do homem novo seriam a abnegação, a disciplina, o entusiasmo e a paixão pela revolução. Esses referenciais, por si sós, estavam intrinsecamente ligados aos signos de coragem e sacrifício atribuídos ao "guerrilheiro revolucionário" e à trajetória particular do próprio Che Guevara, morto em combate na Bolívia no ano de 1967.

\section{GANPHLAC}

Revista Eletrônica da ANPHLAC, ISSN 1679-1061, N. 17, p. 139-168, jul./dez. 2014. http://revista.anphlac.org.br/ 
Nesse sentido, além da busca por transformar a estrutura econômica da ilha, baseada historicamente na monocultura de exportação (produção açucareira), o governo propagou a necessidade de construir uma nova moral social para formar "o homem de consciência verdadeiramente revolucionária, o homem de consciência verdadeiramente socialista, o homem de consciência verdadeiramente comunista" (CASTRO, 1979, p. 16). Ou seja, a população cubana foi convocada a atuar com dedicação e empenho, nos mais diferentes âmbitos, para a construção da nova sociedade socialista.

Ocorreram importantes avanços sociais nas áreas de saúde, educação e emprego, especialmente durante o período de maior crescimento econômico, de 1975 a 1985. Contudo, as transformações em curso na arena internacional a partir do final da década de 1980 geraram intensos impactos na sociedade cubana. A queda do muro de Berlim, em 1989, e a desfragmentação do campo soviético representaram o isolamento político e econômico de Cuba, fato que motivou a construção de novos rumos nas ações estratégicas do governo socialista. Essa nova fase política e econômica foi denominada oficialmente como "Período Especial em Tempos de Paz", mas passou a ser habitualmente chamada apenas de Período Especial.

Este processo teve início oficialmente em 1991, mas Fidel Castro já fazia menções às possibilidades de recrudescimento econômico desde janeiro de 1990. Castro (1990) anunciou que, ainda que na vigência de um contexto de "paz", a população cubana deveria estar preparada para um período de obstrução do abastecimento da ilha, problemática esperada somente em um contexto de guerra. ${ }^{10} \mathrm{O}$ desabastecimento era um grande temor, visto que produtos impulsionadores de setores essenciais da economia, como o petróleo, provinham basicamente de importações do Leste Europeu. ${ }^{11}$

\footnotetext{
${ }^{10}$ No discurso de encerramento do XVI Congreso da Central de Trabajadores de Cuba, em 1990, o líder advertiu: "Hace 10 años venimos reforzando nuestras defensas, venimos aplicando la concepción de la guerra de todo el pueblo. [...] Hemos elaborado planes para todas las variantes, comenzando por el bloqueo militar total del país, en cuyo caso aquí no podría llegar ni una bala. [...] Hemos organizado el país en zonas de defensa. Hombre, mujeres, niños, jóvenes, y ancianos están organizados; todo el país está organizado para cobrar un precio impagable a los agresores, para ocasionarles tanto daño y tantas bajas que no les quedara otra alternativa que retirarse del país. [...] Sin embargo, pueden venir otras variantes para las cuales tenemos que prepararnos. Nosotros llamamos a ese período de bloqueo total, período especial en tiempo de guerra; pero ahora tenemos que prepararnos por todos estos problemas, e incluso hacer planes para un período especial en tiempo de paz" (CASTRO, 1990).

${ }^{11}$ Segundo o economista cubano Carmelo Mesa-Lago (2005, p. 184), entre os anos de 1960-1990 a União Soviética concedeu 65 milhões de dólares para Cuba. Esse valor não inclui o dinheiro fornecido por
}

\section{GANPHLAC}

Revista Eletrônica da ANPHLAC, ISSN 1679-1061, Nº. 17, p. 139-168, jul./dez. 2014. http://revista.anphlac.org.br/ 
Com o efetivo desaparecimento de seus principais aliados políticos e o advento do Período Especial, a ilha entrou na mais intensa crise econômica de toda a sua história nos anos 1990, quando ocorreu um verdadeiro colapso na economia.

O produto interno bruto (PIB) cubano caiu vertiginosamente: -2,90\% em 1990; $10 \%$ em 1991; $-11,6 \%$ em 1992; e -14,9\% em 1993, o pior ano da crise econômica. Como as autoridades temiam, houve uma drástica redução nos índices das importações, a capacidade foi reduzida em $70 \%$ entre os anos de 1989 e 1992. Com o desaparecimento do mercado-alvo, também ocorreu a redução das exportações, pois a URSS era a compradora de $63 \%$ das exportações de açúcar, $95 \%$ dos cítricos e $73 \%$ do níquel. Além disso, o açúcar cubano perdeu o subsídio oferecido pelo mercado soviético e passou a ser comprado no mercado internacional pelas taxas convencionais. Houve ainda a supressão total dos financiamentos estrangeiros, passando de 3 bilhões de dólares em 1989 para zero em 1992. Assim, o abalo econômico teve dimensões sem precedentes na história do país (GOTT, 2006, 322-323).

Durante a primeira metade da década de 1990, os anos mais críticos do Período Especial, prevaleceu a lógica da escassez e da política de racionamento. O contexto foi marcado pela insuficiência ou pelo desaparecimento de produtos importantes, principalmente artigos industrializados, como itens de higiene pessoal e para o lar, alimentos enlatados, papel, roupas, calçados e medicamentos. Além disto, ocorreu o racionamento de eletricidade (em algumas regiões aconteciam apagões diários de até oito horas); racionamento nas transmissões de televisão (houve a redução para cinco horas diárias de segunda a sexta-feira, nove horas aos sábados e quatorze horas de transmissão aos domingos); e o racionamento de combustível, tanto para o uso doméstico (gás de cozinha) como para o transporte (no âmbito do transporte coletivo encaravam-se dificuldades com a demora, a superlotação e a supressão de linhas de ônibus). Tais situações geraram consequências no desenvolvimento da dinâmica familiar, provocando uma crise na administração do tempo, já que simples atividades, como se deslocar até o espaço de trabalho ou cozinhar para a família, passou a demandar muito mais tempo (AGUILAR, POPOWSKI, VERDESES, 1996).

outros países do Conselho de Assistência Econômica Mutua (COMECON), a união econômica dos países comunistas, que Cuba integrava desde 1972.

\section{GANPHLAC}

Revista Eletrônica da ANPHLAC, ISSN 1679-1061, N. 17, p. 139-168, jul./dez. 2014. http://revista.anphlac.org.br/ 
A partir da alegação de tentar salvar a economia e as conquistas sociais da revolução, o governo introduziu algumas mudanças institucionais, como a promulgação de uma Nueva Ley Electoral e a reforma da constituição, ambas no ano de $1992 .^{12}$

Além disso, o governo recorreu a outras estratégias na área econômica, como a aprovação do investimento de capital estrangeiro (foram criadas empresas mistas e de capital privado) em diversos setores da economia; a introdução do trabalho autônomo tributado em alguns ramos profissionais; a abertura do mercado interno; a despenalização do dólar ${ }^{13}$ e a abertura de casas de câmbio; a criação do peso convertible, que levou à circulação de duas moedas na ilha ${ }^{14}$; a abertura do mercado agropecuário, que passou a ser regido pela lei de oferta e demanda; a reorganização da produção agropecuária através do cooperativismo; a racionalização do aparato estatal; a redução dos postos de trabalho; o investimento no setor do turismo internacional; a aplicação de uma política físcal, entre outras ações (BOBES, 2001; HOLGADO, 2002).

O investimento de capital estrangeiro na ilha havia cessado desde os primeiros anos da revolução, mas, com o advento da crise, a primeira empresa de capital misto foi criada na área do turismo ainda em 1988. Em maio de 1995 já existiam 212 associações econômicas, com capital proveniente de 53 países, distribuídos em 34 setores diferentes. A partir da Ley de Inversión Extranjera, aprovada em 1995, admitiu-se pela primeira vez a formação de empresas de capital totalmente estrangeiro no território insular (BOBES, 2001, p. 82).

Um dos pilares fundamentais do processo de abertura econômica foi a inserção de empresas estrangeiras no setor turístico, oriundas principalmente do Canadá e da

\footnotetext{
${ }^{12} \mathrm{~A}$ reforma da constituição provocou transformações no caráter irrevogável da propriedade socialista. A partir de então, autorizam-se a aquisição, a transmissão plena de propriedade e a operação em divisas para diferentes tipos de entidades cubanas por pessoas ou grupos de qualquer nacionalidade (HAVRANEK, 1998, p. 164).

${ }^{13}$ O uso do dólar por cubanos foi penalizado até agosto de 1993, a posse da moeda norte-americana poderia gerar a condenação a até 15 anos de prisão. Até este momento, as lojas que vendiam artigos em dólares, espécies de supermercados, só eram permitidas para diplomáticos, residentes estrangeiros, turistas e a elite governamental (HOLGADO, 2002, p. 40).

${ }^{14} \mathrm{O}$ peso convertible, também denominado de CUC, divisas ou dólar, foi criado depois da despenalização da posse do dólar norte-americano, em agosto de 1993. Com a criação do CUC e a abertura das casas de câmbio (CADECA) em 1995, houve a estabilização das conversões e, assim, foi estabelecida a taxa de câmbio de 1 peso convertible para cada 25 pesos cubanos (HOLGADO, 2002, p. 41). Ou seja, os trabalhadores das empresas de capital misto ou estrangeiro possuem grande vantagem frente à remuneração dos trabalhadores das empresas estatais.
}

\section{GANPHLAC}

Revista Eletrônica da ANPHLAC, ISSN 1679-1061, Nº. 17, p. 139-168, jul./dez. 2014. http://revista.anphlac.org.br/ 
Espanha. Assim, a partir da década de 1990, as visitas de turistas estrangeiros, que até então eram mal vistas pelo governo revolucionário, por serem consideradas como favoráveis às más influências da mentalidade capitalista, passaram a ser visadas como uma importante alternativa econômica. Em vista disso, nas últimas duas décadas, a sociedade cubana passou a encontrar no turismo uma de suas principais fontes de recursos. Segundo Mesa-Lago (2003, p. 200), o número de turistas cresceu de 2.770 em 1989 para 1.773.986 no ano 2000. E a receita bruta do turismo cresceu 11,5\%, passando para 1.948 milhões de dólares no período entre 1989 e 2000.

Dessa forma, com a grande valorização do aporte econômico proveniente desse setor, foram sancionadas leis que concederam certos privilégios aos investidores e turistas estrangeiros em detrimento dos direitos da população nacional, como a restrição dos últimos, para acessar espaços destinados ao turismo. Assim, para garantia do conforto e privacidade de alguns, foi negado o direito da maioria, aos nacionais, de entrar em determinadas zonas do país, principalmente as praias (como Varadero e Los Cayos), além da restrição para entrar em hotéis. Esse fenômeno social foi denominado pela antropóloga Ana Alcázar Campos (2009, p. 3) como “apartheid turístico". ${ }^{15}$

As transformações e reformas que ocorreram durante o Período Especial originaram redefinições na base de estratificação da sociedade e o crescimento nos índices de diferenciação econômica entre a população, criando divisões entre os que possuíam e os que não possuíam acesso ao dólar, potencializando as diferenciações de consumo entre os cubanos.

Segundo Velia Bobes (2001, p. 84), a homogeneização austera do consumo desde o princípio da década de 1960 havia atenuado, em certa medida, as tensões das identidades individuais como campo problemático na sociedade socialista ${ }^{16}$. No entanto, a partir dos anos 1990, as novas condições sociais demonstraram o fim do projeto de uniformidade, visto que os diferentes grupos começaram a distanciar-se em relação aos

\footnotetext{
${ }^{15}$ Somente no ano de 2008, o presidente Raúl Castro revogou as leis que proibiam o acesso de cubanos a determinados espaços do território voltados para o turismo, apesar da vigência de leis que protegem os estrangeiros de serem "importunados" e assediados por nacionais. Segundo Alcázar (2009), mesmo sem a segregação espacial, continua prevalecendo o "apartheid econômico", que distancia a população cubana dos espaços votados para o turismo, todos tarifados com a nova moeda.

16 Entre outras medidas, houve a criação da libreta de abastecimento, em 1963 para racionar a alimentação, assegurando uma cota mínima de artigos subsidiados a todos os cidadãos.
}

\section{GANPHLAC}

Revista Eletrônica da ANPHLAC, ISSN 1679-1061, No. 17, p. 139-168, jul./dez. 2014. http://revista.anphlac.org.br/ 
níveis e tipos de consumo e, com isso, começaram a surgir "estilos de vida" muito distintos entre si.

Esse cenário gerou inclusive, o surgimento de novos atores sociais $\mathrm{e}$ econômicos no contexto revolucionário, como a figura do empresário capitalista estrangeiro; o funcionário das empresas de capital misto ou estrangeiro que recebe em CUC; o trabalhador por conta-própria ${ }^{17}$; o desempregado (resultado das medidas de racionalização de empregos), além dos indivíduos que desenvolvem atividades econômicas ilícitas, como os que atuam no denominado "mercado negro" e as prostitutas (habitualmente denominadas de jineteras). Bobes (2001, p. 86) aponta que tal diversificação dos sujeitos socioeconômicos, em uma sociedade que viveu mais de três décadas sob a absoluta centralização estatal e cujo discurso estava baseado na homogeneização social, expõe o aumento das tensões sociais vigentes nesse contexto.

Ainda assim, mesmo após o desenvolvimento de inúmeras reformas que consolidaram uma economia de caráter misto, o governo manteve a retórica de defesa do socialismo, acentuando a ênfase na heroica luta nacionalista do povo cubano (ROJAS, 2009). Essa perspectiva ignorou as mudanças, como se as novas políticas em curso não estivessem proporcionando outros contornos ao que até aquele momento se conhecia como "socialismo cubano".

Em discurso proferido no ano de 1995, Fidel Castro (2006, p. 243) defendeu que, frente às adversidades da crise, o exercício do sacrifício da população revelava-se como um elemento essencial na luta para salvar as conquistas do socialismo, já que seriam inevitáveis determinados retrocessos:

derivados de esta circunstancia del Periodo Especial, de las medidas que tomamos, de estos elementos de capitalismo que nos vemos obligados a introducir de estos elementos de mercado que nos vemos obligados a introducir, y que establecen esas diferencias que nos duelen y con las cuales no nos queda más remedio que coexistir, porque preferible es coexistir con algunos de estos problemas que perder la Patria, que perder la Revolución, que perder las conquistas que ha alcanzado nuestro país. Algo tenemos que sacrificar. (CASTRO, 2006, p. 245)

\footnotetext{
${ }^{17}$ O trabalho autônomo foi autorizado legalmente em Cuba a partir de setembro de 1993, através do Decreto-Lei 141, mas é válido apenas para alguns ofícios, a exemplo da administração privada de bares e restaurantes, que estavam fechados desde março de 1968 (GOTT, 2006, p. 327).
}

\section{GANPHLAC}

Revista Eletrônica da ANPHLAC, ISSN 1679-1061, N. 17, p. 139-168, jul./dez. 2014. http://revista.anphlac.org.br/ 
E se de fato não existiam outros meios para enfrentar a crise, a não ser implantar componentes da estrutura capitalista na economia cubana, e, segundo Fidel, algumas coisas seriam sacrificadas durante esse processo, resta identificar o que as novas diretrizes do "socialismo de mercado" elegeram para sacrificar em favor da defesa da pátria e das conquistas da revolução.

Ademais, nota-se que a crise econômica não motivou transformações somente no âmbito financeiro, modificando apenas as possibilidades de acesso aos bens de consumo da população. O período especial provocou abalos nos valores de coletividade e igualdade, pilares do projeto revolucionário, o que consequentemente atingiu de modo profundo o imaginário de unidade social. Especialistas apontam que o Período Especial, para além da crise econômica, representou uma crescente crise na ética e nos valores revolucionários (BOBES, 2001; FELIPE, VÁLDES, 1996; HOLGADO, 2002). A crise do Período Especial representou uma ruptura na dinâmica cotidiana dos cubanos, com a reestruturação dos esquemas referenciais de pensamento e ação, em diferentes esferas.

Dessa forma, a diversificação das fontes de ingresso gerou mudanças na percepção subjetiva da população, que afetou inclusive a valorização social da educação e do trabalho, pois a dedicação a essas duas atividades deixou de ser o meio fundamental para a obtenção de recursos econômicos. ${ }^{18}$

Esse quadro também provocou o incremento da desocupação e o subemprego, a intensificação da estratificação social, o aumento da corrupção administrativa e policial $^{19}$, a superlotação e a deterioração das moradias, a instabilidade nas relações maritais, além do crescimento do individualismo, da agressividade e dos índices de violência. No que se refere a este último fenômeno social, particularmente, dados oficiais apontam para o aumento de $27 \%$ dos atos de delinquência na década de 1990 -

\footnotetext{
${ }^{18} \mathrm{~A}$ partir do fenômeno de inversão da pirâmide de ingressos, em que pessoas que possuíam qualificação profissional inferior passaram a obter remunerações mais vantajosas que os demais por receberem em peso convertible, registrou-se uma "[...] cierta reducción en el nivel de escolarización de las edades entre 15 y 16 años, que tiene entre otras causas el desinterés relativo por la superación individual, en la medida en la que comienza a no ser identificada como la vía fundamental de ascenso social". (FELIPE, VÁLDES, 1996, p. 105)

${ }^{19}$ As atividades ilícitas no meio estatal são basicamente práticas como o suborno de funcionários, o desvio de mercadorias de armazéns estatais e a subtração de finanças e equipamentos das instituições.
}

\section{GANPHLAC}

Revista Eletrônica da ANPHLAC, ISSN 1679-1061, N. 17, p. 139-168, jul./dez. 2014. http://revista.anphlac.org.br/ 
mais da metade dessas ações foram contra a propriedade estatal (HOLGADO, 2002, p. 223).

Segundo a historiadora Almudena Olondo (2006, p. 154), o novo contexto forjou a incidência de certa flexibilidade ética e moral. Devido às inúmeras carências materiais, passou a ser relativamente aceito no meio social "resolver" os problemas pelos meios individuais disponíveis, o que fica explícito na formulação do seguinte ditado popular vigente no período: "Aquí todo el mundo roba, y gracias a esto todo el mundo vive" (OLONDO, 2006, p. 154). Ou seja, para além da crise econômica, o Período Especial impulsionou uma crise de valores, constituindo novos códigos de sociabilidade na ilha.

Nesse sentido, como consequência da construção de novos códigos de sociabilidade, além dos fenômenos da desocupação e da des-profissionalização, o "recurso que mostra la cara menos benévola de la actividad en el sector informal lo constituye la prostitución” (MOLYNEUX, 2003, p. 144) ou jineterismo. ${ }^{20}$

A problemática da prostituição, declarada como resolvida oficialmente em $1965^{21}$, tornou-se explicitamente visível com o advento da crise nos anos 1990, a ponto de o governo se ver obrigado a reconhecer a existência do problema, devido à intensa repercussão na imprensa internacional do "retorno da prostituição em Cuba". 22

\footnotetext{
${ }^{20}$ A análise do neologismo cubano jinetera(o) aponta para a complexidade presente nas relações sociais e econômicas entre cubanos e estrangeiros a partir dos anos 1990, incluindo a atividade da prostituição. Segundo as análises "[...] el jineterismo es actualmente usado para describir un amplio rango de actividades relacionadas con el acoso al turista (incluyendo la venta en el mercado negro de cigarros, ron, joyas de coral, etc.), provisión de servicios de taxi o acceder a los "auténticos" rituales de santería, o simplemente sirviendo como guías informales a cambio de comida gratis o algunos regalos del turista. Aparte de estos negocios a nivel de calle, el término es también aplicado, frecuentemente, fuera del área del turismo para referirse a cualquier actividad generadora de dólares o conectada con extranjeros [incluida el intercambio sexual]" (FERNÁNDEZ, 1999, p. 85 apud ALCÁZAR, 2009, p. 11).

${ }^{21}$ Segundo especialistas, como Teresa Díaz Canals e Graciela González Olmedo (1997, p. 173), existiram focos de prostituição associados à atividade marítima e portuária durante os anos 1970 e 1980, além de manifestações da prostituição dirigida a homens que ocupavam altos postos do escalão do governo, do exército e da diplomacia. Reynaldo Escobar denomina as mulheres destinadas a esse tipo de prostituição como cortesanas del socialismo real. (ESCOBAR, 1997, p. 66)

${ }^{22}$ Segundo a retórica oficial, a grande repercussão sobre o ressurgimento desse fenômeno social na imprensa estrangeira correspondia a um exagero, motivado pelo interesse político de desprestigiar a imagem da revolução. De modo irônico, a jornalista cubana Rosa Miriam Elizalde afirmou: "A juzgar por el bombardeo informativo en la prensa extranjera todas las cubanas, de una vez, nos dedicamos a la prostitución". (ELIZALDE, 1996, p. 19)
}

\section{GANPHLAC}

Revista Eletrônica da ANPHLAC, ISSN 1679-1061, N. 17, p. 139-168, jul./dez. 2014. http://revista.anphlac.org.br/ 
Ademais, a prostituição se tornou um tema notório na produção cultural cubana dos últimos anos, principalmente na literatura e no cinema. ${ }^{23}$

No entanto, o Estado construiu um discurso, reproduzido também pela imprensa local e por muitos intelectuais cubanos, que culpabilizava as mulheres classificadas como prostitutas. $\mathrm{O}$ argumento incidia na ideia de que as jineteras não realizavam essa atividade motivadas por uma condição de miséria, como acontecia no contexto anterior à revolução, mas porque seriam inspiradas pelo desejo de lucro fácil ${ }^{24}$, ademais, de sua "fraqueza moral". ${ }^{25}$

A própria Federação de Mulheres Cubanas (FMC), única organização de mulheres da ilha, corroborou com a perspectiva do governo sobre as motivações do jineterismo. Em fevereiro de 1995, nas vésperas do VI Congresso da FMC, Vilma Espín - presidenta vitalícia da organização - declarou:

dolorosos son los casos de prostitución que han aparecido entre gente débil, familias sin ética, muchachas que son una gran verguenza para el país y no reparan en la degradación moral que padecen. [...] La mayoría proceden de hogares con poca ética o sencillamente, gente muy depravada que acepta que sus hijas vivan así porque también se benefician. Muchas son jóvenes desarticuladas del hogar y unas pocas sin que la familia lo sepa. Al menos ésas tienen un mínimo de moral, sienten alguna verguenza. (Granma 28/02/1995 apud HOLGADO, 2002, p. 258)

\footnotetext{
${ }^{23}$ Alguns exemplos em obras literárias são: Trilogía sucia de La Habana (1998), de Pedro Juan Gutiérrez, Alguién tiene que llorar (1997), de Marilyn Bobes, e Silencios (1996), de Karla Suárez. No cinema, as obras de ficção Los dioses rotos, de Ernesto Daranas, Fábulas, dirigida por Lester Hamlet, Extravíos, de Alejandro Gil Álvarez, Club Habana, de Jorge Herrera, Chamaco, de Juan Carlos Cremata, e os documentários, Sexo, historias y citas de video de Ricardo Figueredo, Sucedió en La Habana, de Henry Eric e Dull Janiell, e ¿Quién diablos es Yuliet?, dirigida por Carlos Markovich. Mas ainda prevalece a representação de que a prostituição é uma prática desenvolvida unicamente por mulheres, dos títulos mencionados acima somente o longa-metragem ficcional Chamaco e Trilogía sucia de La Habana abordam o tema da prostituição masculina, além dos documentários.

${ }^{24}$ A prática do jineterismo possui um sentido econômico, já que o(a) parceiro(a) afetivo-sexual oferece recursos financeiros e/ou o acesso a bens e serviços, mas a relação não se encerra nisso. O jineterismo se constitui também como uma alternativa para a imigração legal, já que o casamento com estrangeiros consiste em uma das poucas alternativas para obter a permissão legal para sair do país. Dessa forma, essa atividade extrapola o sentido econômico, ao oferecer também a acepção de liberdade para pessoas que compreendem a impossibilidade legal de sair do país como sinônimo de privação de um direito fundamental.

${ }^{25}$ As psicólogas cubanas Díaz, Martín e Perera (1996, p. 97) denominam a prática do jineterismo e os delitos de modo geral como quadro patológico de autodestruição e respostas anti-sociais. Já Aguilar, Popowski e Verdeses (1996, p. 15), estudiosas vinculadas à Area de Estudios de la Mujer da Federación de Mujeres Cubanas (FMC), afirmam que as jineteras são fracas moralmente, além de mulheres que buscam fáceis e espúrios benefícios materiais.
}

\section{GANPHLAC}

Revista Eletrônica da ANPHLAC, ISSN 1679-1061, Nº. 17, p. 139-168, jul./dez. 2014. http://revista.anphlac.org.br/ 
Ou seja, para a presidenta da FMC as jineteras são provenientes de famílias depravadas e sem ética. Espín reitera ainda que essas mulheres representam uma verdadeira vergonha para a honra da nação.

Para o jornalista cubano Reinaldo Escobar (1997), a questão é muito mais complexa do que o discurso oficial deix a transparecer, ${ }^{26}$ até porque, em um curto espaço de tempo conformou-se uma ampla rede que fomenta e se beneficia com o turismo sexual. Essa rede inclui funcionários de hotéis e restaurantes, taxistas, fotógrafos, funcionários de agências de viagens no exterior, proxenetas e, até mesmo, policiais (HOLGADO, 2002, p. 245), que realizam extorsões em troca de poupar as jineteras da prisão. $^{27}$

O Estado tem conhecimento da existência dessa rede que atua em torno do turismo sexual e, aparentemente, tenta reprimi-la, ainda que de modo ambíguo. ${ }^{28}$ Mas, ao mesmo tempo, o próprio governo cubano, ao estimular o turismo internacional, um dos principais focos da economia atual, está rearticulando e reproduzindo representações acerca da desinibição sexual das mulheres cubanas, o que paradoxalmente estimula o turismo sexual.

Os principais alvos da propaganda sexualizada na área do turismo, promovido tanto por empresas cubanas de capital misto como por empresas estrangeiras, são mulheres negras e mulatas (ÁLVAREZ, 2003, p. 30; BOBES, 2001, p. 90; HOLGADO, 2002, p. 242; KNEESE, 2005, p. 449). A pesquisa da psicóloga cubana Norma Guillard

\footnotetext{
${ }^{26}$ Para o jornalista, "El hambre es también un problema cultural. No sólo se pasa hambre cuando se llega al nivel de inanición de un náufrago abandonado sobre una roca estéril. Hambre es también no poder elegir los alimentos, no poder condimentarlos a nuestro gusto, no tener una dieta balanceada. Pero además las necesidades humanas no son sólo digestivas. Una persona necesita asearse, vestirse, rodearse de objetos útiles. Renunciar al consumismo no significa volverse un anacoreta. Pretender comprar un ventilador cuando se vive en una habitación sin ventanas no es un acto consumista". (ESCOBAR, 1997, p. 67)

${ }^{27}$ A prostituição e o proxenetismo foram incluídos no indice de peligrosidad predelictiva, definidos como condutas impróprias em 1999. O controle é empreendido pelo policiamento, que aplica advertências oficiais. A partir da terceira advertência, os infratores são direcionados para Centros de Clasificación e Internamiento, para trabalhar em atividades agrícolas com a finalidade de se reeducar para a sua reinserção na sociedade. Caso sejam reincidentes, são punidos(as) com até oito anos de privação de liberdade. (HOLGADO, 2002, p. 255)

${ }^{28}$ A repressão ao fenômeno da prostituição é muito ambígua, uma vez que os turistas estrangeiros, majoritariamente homens, não são penalizados pela compra dos serviços sexuais, somente os profissionais do sexo identificados pelo policiamento, que são majoritariamente mulheres.
}

\section{GANPHLAC}

Revista Eletrônica da ANPHLAC, ISSN 1679-1061, N. 17, p. 139-168, jul./dez. 2014. http://revista.anphlac.org.br/ 
(2004) sobre a representação da figura da mulher negra na publicidade demonstra que a reprodução de sua imagem é quase nula. Porém, quando sai da invisibilidade, sua representação ocorre basicamente em anúncios de turismo onde jovens negras e mestiças aparecem seminuas.

Desse modo, reedificando imaginários historicamente construídos de que Cuba é um paraíso de indulgência sexual, o Hotel Sol Palmeras, da cidade de Varadero, um dos principais destinos turísticos da ilha, expressou a seguinte frase em um anúncio publicitário: "Cuba: fuego y pasión de sabor caribeño.". E a Cubatur, agência de viagens estatal, proclama, por meio da publicidade: "Esta isla merece amor" (DE LA FUENTE, 2001, 448). Além disso, o Instituto Nacional de la Industria Turística e a agência de viagens estatal Cubanacán foram os anfitriões de uma equipe da revista Playboy que viajou a Cuba em 1991, para realizar uma matéria em que lindas jovens apareceram seminuas (HOLGADO, 2002, p. 256).

Como se vê, paradoxalmente, o mesmo governo que condena as mulheres envolvidas na prostituição, parece concordar com - e até mesmo elabora - propagandas com mensagens que fomentam representações da existência de uma suposta sexualidade tropical incontrolável.

Portanto, esse paradoxo indica qual foi o grupo social que as novas diretrizes da economia mista ou do "socialismo de mercado" elegeram para sacrificar, em favor da defesa da pátria e das conquistas da revolução, como postulou Fidel: mulheres jovens, especialmente as jovens negras e mulatas, ${ }^{29}$ foco da propaganda sexualizada, que beneficia a rede de turismo sexual e a própria economia, apoiada no turismo a partir dos anos $1990 .^{30}$

\section{Trilogía sucía de La Habana: a crise econômica, a crise de valores e a crise subjetiva}

\footnotetext{
${ }^{29} \mathrm{O}$ retorno do fenômeno social da prostituição em Cuba se fundamenta nas antigas hierarquias sociais de gênero e raça que constituem as representações sociais das mulheres negras, principalmente as mulatas, sob o mito de sua disponibilidade e destreza sexual. (KNEESE, 2005, p. 449)

30 Alguns estudiosos defendem a interpretação de que o jineterismo, para além de uma atividade econômica, representa uma prática de oposição ao regime, por atentar contra a ordem androcêntrica, contra a ênfase ao trabalho produtivo, contra os valores anticonsumistas e contra a moral puritana da revolução. (OLONDO, 2006, p. 159)
}

\section{GANPHLAC}

Revista Eletrônica da ANPHLAC, ISSN 1679-1061, N. 17, p. 139-168, jul./dez. 2014. http://revista.anphlac.org.br/ 
O jornalista, escritor e pintor cubano Pedro Juan Gutiérrez nasceu na província de Matanzas em 27 de janeiro de 1950. Gutiérrez dedicou-se a diferentes ofícios, mas o jornalismo foi a atividade em que atuou por mais tempo, 26 anos. ${ }^{31}$ Após a publicação de alguns livros, ${ }^{32}$ o autor publicou na Espanha, em 1998, a Trilogía sucía de La Habana. Esse livro de contos foi a primeira e principal obra do denominado Ciclo Centro Habana. ${ }^{33}$ Com imediato sucesso e grande repercussão, a obra foi editada e publicada em outros vinte países.

A Trilogia suja de Havana (1998) aborda os conflitos sociais e subjetivos do personagem Pedro Juan, homônimo ao autor, no contexto do Período Especial, entre 1994 e 1997. O protagonista é um ex-jornalista de 44 anos, que vive em meio ao caos e luta pela sobrevivência. A partir deste momento, utilizarei Gutiérrez para designar o autor e Pedro Juan como referência ao protagonista.

De modo irônico, Gutiérrez joga com as similaridades entre a sua trajetória pessoal e a história de vida do protagonista Pedro Juan, forjando confrontações entre o real e a ficção. Por meio de recursos estruturais, como a narrativa em primeira pessoa, o batismo do principal personagem com o seu próprio nome, profissão, cidades de nascimento e residência idênticas, além da coincidência da faixa etária, a obra ganha contornos realistas e autobiográficos. ${ }^{34}$ Contudo, para Paula Carvalho Coelho e Ana Lucia Trevisan (2011, p. 16) a Trilogia não se enquadra no gênero autobiográfico, mas na condição de obra híbrida, que mistura elementos de ficção e realidade.

Os estudiosos das obras de Gutiérrez filiam a sua produção à vertente literária do realismo sujo. Anke Birkenmaier (2004) expõe que, na América Latina, essa tendência

\footnotetext{
${ }^{31}$ Pedro Juan Gutiérrez formou-se em jornalismo pela Universidade de La Habana em 1978; trabalhou em rádio, televisão, agências de notícias e na importante revista semanal Bohemia. Como jornalista, Gutiérrez visitou diferentes países, como a União Soviética, Alemanha Oriental, Brasil, México e Espanha.

32 O jornalista e escritor já havia publicado em Cuba o livro de não ficção Vivir en el espacio (1989) e o fictício Cuentos de La Habana vieja (1997), na Espanha.

${ }^{33}$ Os cinco livros do autor que compõem o Ciclo Centro Habana são os seguintes: Trilogía sucia de la Habana (1998); El rey de La Habana (1999); Animal tropical (2000); El insaciable hombre araña (2002); e Carne de perro (2003).

${ }^{34}$ A escolha da narrativa em primeira pessoa e o flerte com o autobiográfico são características da literatura cubana recente, especialmente na produção dos novisímos. Segundo o crítico Miguel GonzálezAbellas (2005), essas estratégias narrativas buscam aprofundar a credibilidade dos leitores pelo texto, devido à tendência ao reconhecimento de autoridade, para expressar algo com conhecimento de causa.
}$$
\text { GANPHLAC }
$$

Revista Eletrônica da ANPHLAC, ISSN 1679-1061, N. 17, p. 139-168, jul./dez. 2014. http://revista.anphlac.org.br/ 
possui particularidades que a distanciam do Dirty Realism norte-americano. ${ }^{35}$ Presente tanto na produção literária como na cinematográfica, o realismo sujo latino-americano caracteriza-se por uma estética de violência que compõe o excesso de brutalidade nas relações dos personagens e a maneira veloz com que essas situações ocorrem. Como estrutura, a narrativa é construída após catástrofes e momentos decisivos; com isso, criam-se mentalidades violentas, consonantes a contextos de guerra. Apesar disso, os autores demonstram pouco interesse nos fatos históricos e no debate sobre o contexto social, construindo o foco nas histórias individuais e marginalizadas dos protagonistas.

Essas características do realismo sujo estão presentes na Trilogia suja de Havana. As mortes existentes na obra são quase sempre repentinas e violentas, motivadas por assassinatos e suicídios. A catástrofe é representada pela queda do bloco soviético e pelas consequências da crise econômica e moral desencadeada na ilha. $\mathrm{O}$ empenho individual de Pedro Juan em subsistir, somado à sua busca pela indiferença política, apresentam-se como outras similitudes a essa vertente literária. Todavia, percebe-se a existência de muitas correlações entre a narrativa de Gutiérrez e a produção literária dos "novíssimos", ${ }^{36}$ vertente de maior destaque em Cuba durante os anos $1990 .^{37}$

A obra possui como foco as relações cotidianas na capital da ilha, centradas principalmente no bairro de Centro Habana, ${ }^{38}$ onde personagens marginais compõem o cenário de uma cidade em ruínas. A partir da apropriação de códigos e representações

\footnotetext{
${ }^{35}$ Segundo Birkenmaier (2004), o realismo sujo norte-americano caracteriza-se pela pouca ação, em narrativas dedicadas ao detalhe, com revelações sobre um ambiente ou um momento específico. As principais referências desse contexto são Raymond Carver, Tobias Wolff e Richard Ford.

${ }^{36}$ Eclodiu uma nova geração de narradores entre o final da década de 1980 e o início dos anos 1990, denominada como novissimos. Esses autores surgiram em um contexto de grande instabilidade, com reformas políticas e econômicas no socialismo cubano. Envolvidos com tais vicissitudes, seus autores utilizaram a literatura como testemunho do cenário de grandes transformações. Os principais temas explorados versavam sobre a crise econômica, a crescente marginalidade, a sexualidade, a participação cubana na guerra de Angola e a criação literária.

${ }^{37}$ Tal proximidade se estabelece tanto em aspectos temáticos como estilísticos, assim como o forte conteúdo de oralidade, a ênfase no caráter testemunhal da narrativa e a própria utilização do conto como o principal gênero literário.

${ }^{38}$ Centro Habana é considerado um barrio marginal, modo como são denominadas as áreas periféricas apesar de Centro Habana não estar localizado numa zona periférica em relação ao centro. Segundo o antropólogo cubano Pablo Rodríguez Ruiz (2011), a maioria dos bairros marginais da cidade de La Habana é oriunda da ocupação ilegal, onde a população edifica habitações improvisadas e compartilha de condições estruturais precárias e insalubres. Negros e migrantes de outras províncias da ilha prevalecem entre os moradores desses bairros.
}

\section{GANPHLAC}

Revista Eletrônica da ANPHLAC, ISSN 1679-1061, N. 17, p. 139-168, jul./dez. 2014. http://revista.anphlac.org.br/ 
sociais que regem esse contexto, o autor expõe diferentes conflitos e tensões sociais, incluindo temas considerados tabus na sociedade cubana durante a experiência socialista, como corrupção, violência, homossexualidade, opressão de gênero, racismo, imigração, suicídio, repressão, "mercado negro" e a prostituição feminina e masculina.

Com grande uso de coloquialismos, típicos da linguagem oral, como o uso de ditados populares e palavrões, o autor apresenta um cenário caótico, deflagrado pela crise que se desenha na narrativa em três grandes planos: a crise econômica, a crise de valores e a crise existencial vivenciada pelo protagonista.

A primeira delas, a crise econômica, evidencia-se a partir da luta cotidiana de Pedro Juan e dos personagens coadjuvantes, para garantir a subsistência por meio de atividades lícitas e ilícitas, além das migrações e imigrações ilegais, a superlotação de moradias, a deterioração e a queda de edifícios etc.

Pedro Juan dedicou-se por mais de vinte anos ao jornalismo, mas foi demitido no início dos anos 1990 e passou a viver em um cortiço no bairro de Centro Habana, onde subsistia a partir de subempregos e atividades ilícitas. Ele foi vendedor de sorvetes, desentupidor de encanamento, reformou colchões, recolheu moradores de rua e também foi lixeiro. No campo da ilegalidade, o personagem foi catador de latinhas, proxeneta, prostituto, além de vendedor de artigos no "mercado negro" (carne de boi, lagosta e maconha).

Durante o Período Especial, quando o dinheiro e a comida eram escassos, ocorreu o incremento da corrupção e da divisão social entre os que tinham acesso e os que não tinham acesso ao dólar. Apontando para a construção de novos códigos de sociabilidade que marcam o segundo plano da crise, na ordem moral, Pedro Juan afirma: "A crise era violenta e chegava até o menor cantinho da alma da gente. A fome e a miséria são feito um iceberg: a maior parte não é visível a olho nu" (GUTIÉRREZ, 2008, p. 113). Parecia não ser possível confiar em mais ninguém, e assim o individualismo passou a ser um mecanismo de autopreservação para o protagonista.

Dessa maneira, imerso neste ambiente de incertezas e desesperança, o terceiro plano dessa difícil conjuntura se instalou no âmbito individual. Uma crise existencial

\section{GANPHLAC}

Revista Eletrônica da ANPHLAC, ISSN 1679-1061, N. 17, p. 139-168, jul./dez. 2014.

http://revista.anphlac.org.br/ 
abalou o protagonista, que passou a sofrer de claustrofobia ${ }^{39}$ e a lutar para resistir na solidão e conter a penetração de sentimentos como o medo, a raiva e a frustração. Ao se sentir sem saída, Pedro Juan declara: "Tinha três opções: endurecia, ficava maluco ou me suicidava. Assim era fácil decidir: precisava endurecer" (GUTIÉRREZ, 2008, p. 28).

Acredito que, neste extrato, o autor faz alusão e se contrapõe à famosa frase de Che Guevara, "Hay que endurecerse, pero sin perder la ternura jamás". Existe uma contraposição, pois o sentido atribuído por Gutiérrez à expressão “endurecer" remete à adoção do cinismo e ao abandono da ética como estratégias de sobrevivência, perspectivas distanciadas de um sentimento como a ternura. Portanto, para não enlouquecer ou suicidar-se, Pedro Juan assumiu como postura o embrutecimento; evadindo-se da existência dos problemas sociais, ele busca não pensar ou se questionar sobre eles, para adaptar-se às novas, e às não tão novas táticas de sobrevivência ilícitas.

A crítica literária Odette Casamayor Cisneros (2004) aponta que a personagem renunciou à perspectiva de fuga do caos e o adotou como se fosse uma religião pessoal. Pedro Juan concentrou-se na prática do sexo e na utilização de drogas (álcool e maconha) como subterfúgios da realidade. ${ }^{40}$

A narrativa de experiências sexuais possui um espaço significativo no livro, a partir de práticas, como o fetichismo, sadomasoquismo, prostituição, voyeurismo, pedofilia, necrofilia e orgias, passando inclusive por atos de violência sexual. O seguinte extrato apresenta a opinião de Pedro Juan sobre o sexo:

O sexo não é para gente escrupulosa. O sexo é um intercâmbio de líquidos, de fluidos, saliva, hálito e aromas fortes, urina, sêmen, merda, suor, micróbios, bactérias. Ou não é. Se for apenas ternura e espiritualidade etérea, não passa de uma paródia estéril do que poderia ser. (GUTIÉRREZ, 2008, p. 10-11)

\footnotetext{
${ }^{39} \mathrm{O}$ personagem passou a sofrer de claustrofobia após um acidente em que ficou preso em um antigo elevador. Como estava entre diferentes andares, ao tentar sair, Pedro Juan ficou com a mão presa e sofreu uma queimadura. A esse respeito, disse: fui "direto para a cadeira do diabo. Claustrofobia galopante. Quando saí do elevador, ou quando me tiraram do elevador, fiquei preso dentro de mim mesmo. E fiquei assim durante muitos anos. Encerrado dentro de mim, desmoronando dentro de mim". (GUTIÉRREZ, 2008, p. 29)

${ }^{40}$ Pedro Juan afirma: "Só andava por aí, caminhando pela minha pequena ilha, conhecendo gente, me apaixonando e fodendo. Trepava muito: o sexo desenfreado me ajudava a fugir de mim mesmo". (GUTIÉRREZ, 2008, p. 28)
}

\section{CANPHLAC}

Revista Eletrônica da ANPHLAC, ISSN 1679-1061, N. 17, p. 139-168, jul./dez. 2014. http://revista.anphlac.org.br/ 
Ao relatar suas experiências sexuais a partir dessa perspectiva visceral, Pedro Juan narra suas práticas com detalhes minuciosos e certo teor de sarcasmo. O narrador almeja "provocar" (GUTIÉRREZ, 2008, p. 80) o leitor e, assim, utiliza-se da noção transgressora presente nas interpretações historicamente construídas sobre a sexualidade nas sociedades ocidentais.

Além disso, no contexto cubano, o puritanismo de alguns dos dirigentes da revolução frente ao erotismo e o grotesco direcionou a constituição do discurso oficial que regeu as políticas culturais no contexto revolucionário durante décadas. A vigência de uma perspectiva conservadora a respeito do sexo motivou a censura de diversas obras literárias desde a década de 1960 (BEHAR, 2007, p. 6).

Contudo, a ênfase discursiva em experiências sexuais não é uma característica exclusiva da obra de Gutiérrez. Relações sexuais transgressoras e a presença de personagens de jineteras, pingueros, ${ }^{41}$ lésbicas e homossexuais é uma forte tendência da narrativa cubana contemporânea.

Diferentes críticos literários (BEHAR, 2007; GONZÁLEZ-ABELLÁS, 2005; SAN MARTÍN, 2006) defendem que o papel central que a prática sexual possui na narrativa cubana no contexto recente está vinculado a um sentido metafórico de crítica ao autoritarismo político presente nessa sociedade. Araceli San Martín (2006, p. 173) afirma:

En estas novelas es muy común que las relaciones sexuales electivas intenten desestabilizar el arquetipo del sujeto heterosexual y machista, símbolo del revolucionario, por medio de relaciones transgresoras tanto por parte del hombre como de la mujer, los temas relacionados con el homosexualismo, las páginas llenas de lesbianas, de jineteras o pingueros evidencian una condición autoritaria.

Ou seja, a ênfase da narrativa de Gutiérrez em relações sexuais pode ter um sentido de contestação do discurso oficial e da ordem social vigente. É possível identificar a construção de críticas ao autoritarismo do governo de modo indireto, nos

\footnotetext{
${ }^{41}$ Pinguero é um termo pejorativo utilizado em Cuba para denominar os homens que se prostituem, oferecendo os seus serviços sexuais a outros homens. Mas, apesar da prática sexual com outros homens, os pingueros não se reconhecem como homossexuais. Essa expressão advém de uma das formas populares de referência ao órgão sexual masculino ("pinga").
}

\section{GANPHLAC}

Revista Eletrônica da ANPHLAC, ISSN 1679-1061, Nº. 17, p. 139-168, jul./dez. 2014. http://revista.anphlac.org.br/ 
contornos da narrativa, em inúmeros trechos, inclusive no que tange à temática da sexualidade. ${ }^{42}$

Nesse sentido, mesmo que a Trilogia suja de Havana tenha sido escrita fora do contexto de orientação mais rígida das políticas culturais da revolução, ${ }^{43}$ o livro nunca foi publicado em Cuba, tal como a maioria das obras de Gutiérrez. ${ }^{44}$ Haja vista que, mesmo que a partir do período especial tenha ocorrido certo afrouxamento das diretrizes mais rígidas da política cultural, foram mantidas inúmeras restrições, especialmente na área editorial, que limitam a publicação de obras que assumem distância ideológica do discurso oficial edificado pelo Estado (ROJAS, 2009).

Nada obstante, acredito que a obra de Gutiérrez não está somente distanciada do discurso oficial do Estado, já que a narrativa questiona e coloca em cheque paradigmas importantes do projeto revolucionário cubano, como o conceito de homem novo, suporte-simbólico-discursivo da cidadania revolucionária.

Questionado na narrativa, como mencionado, o ideário do homem novo foi composto por noções de disciplina, abnegação, adoção de valores coletivistas, a defesa irrestrita da revolução, além da adequação à moral socialista (GUEVARA, 2005). Gutiérrez demarca a ruptura da utopia revolucionária durante o Período Especial e declara a morte do homem novo com a construção de personagens pautados por símbolos opostos ao do modelo oficial. Efetivamente, a trajetória do próprio protagonista pode ser compreendida como a representação do declínio do paradigma do homem novo, pois, imerso nos diferentes âmbitos da crise, Pedro Juan recusa as noções

\footnotetext{
${ }^{42}$ Ao visitar o amigo René, um fotógrafo de meia idade, Pedro Juan relata que ele fora expulso do Partido Comunista, demitido do trabalho, eliminado do Conselho de Jornalistas e abandonado pela esposa, depois de ser flagrado ao tirar fotos de nus fotográficos. E conclui, sarcasticamente: "Cuba em plena construção do socialismo era de uma pureza virginal, de um delicioso estilo Inquisição". (GUTIÉRREZ, 2008, p. 16) ${ }^{43}$ Durante a década de 1970, conhecida como os "anos de chumbo" da política cultural da revolução, chamado também de "Quinquenio Gris" ou década gris. Existe certa divergência acerca de por quanto tempo durou o período de maior endurecimento no campo cultural da revolução. Intelectuais mais oficiosos, como Ambrósio Fornet, reconheceram nos anos 1980 a existência de um "Quinquenio Gris" (quinquênio cinza), compreendido entre o período de 1971 (ano do desfecho do "caso Padilla" e da realização do I Congresso Nacional de Educação e Cultura) e 1975 (ano do I Congresso do Partido Comunista de Cuba). Mas críticos como Pío Serrano contestam que o período de autoritarismo e dogmatismo cultural teria tido a brevidade de cinco anos, segundo ele o período se estenderia de 1971 a 1989 (MISKULIN, 2009, p. 236; VILLAÇA, 2010, p. 267).

${ }^{44}$ Os livros de Pedro Juan Gutiérrez publicados em Cuba são: El rey de La Habana (2009); Animal tropical (2002) e Nuestro GG en La Habana (2006).
}

\section{GANPHLAC}

Revista Eletrônica da ANPHLAC, ISSN 1679-1061, N. 17, p. 139-168, jul./dez. 2014. http://revista.anphlac.org.br/ 
de disciplina, coletivismo e assepsia moral para buscar meios para a sua "salvação" individual.

Fica explicita na narrativa a leitura sobre a decadência vivenciada pela personagem no diálogo entre Pedro Juan e Robertico, um cubano que vive na Europa e está visitando a ilha. Ao contar que havia viajado para Alemanha em 1982, Pedro Juan diz:

- Passei um ano trabalhando em Berlim. Conheci toda a parte socialista. Nessa época eu era jornalista e viajei muitas vezes para a Europa.

- E agora mora no cortiço?

- Moro.

- Porra, compadre, você está na merda! Já tinha morado em cortiço antes?

- Não, mas estou bem. Aqui vou levando. (GUTIÉRREZ, 2008, p. 149)

Encontra-se latente no diálogo que a transição entre o profissional privilegiado que trabalhou fora do país para a condição vulnerável de um desempregado que mora em um cortiço codifica também uma mudança no status social da personagem e das referências simbólicas vigentes. Pedro Juan decreta a morte do homem novo e aponta para a ambição e a má administração do governo como os grandes responsáveis, ao afirmar: "O dinheiro esmaga tudo. Trinta e cinco anos construindo o homem novo. E acabou. Agora isto aqui vai ter que mudar. E rápido. Não é bom ficar para trás”. (GUTIÉRREZ, 2008, p. 92)

O tom de crítica nesse trecho é explícito. Contudo, Gutiérrez brinca ironicamente com a percepção do leitor, as contradições são elementos estruturais de sua estratégia narrativa. A partir de uma postura ambígua, o autor constrói e desconstrói afirmações discursivas compostas por imagens hierárquicas e preconceituosas, especialmente, acerca dos marcadores de gênero, raça e sexualidade. Desta forma, ao mesmo passo que existem afirmações de nítido cunho machista e racista, também existem passagens de crítica a tais noções hierarquizadas; além disto, a classificação racial do protagonista passa por variações em diferentes trechos da narrativa, alterandose de branco para mulato, a depender do contexto, entre outras ambiguidades.

\section{GANPHLAC}

Revista Eletrônica da ANPHLAC, ISSN 1679-1061, N. 17, p. 139-168, jul./dez. 2014.

http://revista.anphlac.org.br/ 
Nesse sentido, se as contradições se fazem presentes de modo constante, no que diz respeito ao ideal do homem novo, além de criticar o governo revolucionário, de modo explícito o autor elabora representações que atribuem noções primitivas e irracionais à população cubana (GUTIÉRREZ, 2008, p. 131). Essas representações não somente ratificam a concepção de ineficiência do projeto político que idealizou formar indivíduos "autenticamente socialistas" como aponta igualmente para a existência de uma natureza grotesca que teria limitado a adaptação ao paradigma revolucionário. ${ }^{45}$

Concordo com o crítico literário Dionizio Marquéz (2007) quando afirma que a Trilogia está composta por diversas forças antagônicas. Para esse autor, a ênfase do livro de Gutiérrez encontra-se na normalidade extrema do cotidiano, e sua "característica central es poner en tela de juicio y simultáneamente reproducir las normas y estereotipos de la cultura y sociedad cubanas". (MARQUÉZ, 2007).

No tocante às contradições discursivas sobre as representações de gênero, existem inúmeras afirmações de cunho pejorativo com relação às mulheres na narrativa. O protagonista se autointitula como "um macho tropical e visceral" (GUTIÉRREZ, 2008, p. 13), que compartilha e defende os códigos de masculinidade hegemônica. Mas, por outro lado, ao mesmo passo em que o protagonista coloca-se como um "macho caribenho" e realiza afirmações com sentido falocêntrico e até misógino, ${ }^{46}$ em alguns trechos da obra ele ironiza e critica a opressão de gênero. Tais críticas ficam nítidas quando, ao tratar sobre o ex-marido de Martica, que a violentou na noite de núpcias, Pedro Juan o define como "um rapaz tosco e machão", um verdadeiro latin lover: "O cara bonito e castigador, o amante tropical perfeito. Imbecil como um touro reprodutor". (GUTIÉRREZ, 2008, p. 75)

Dessa maneira, ao definir o arquétipo do "macho tropical" como imbecil, são desestabilizadas certas figuras discursivas, o autor coloca em cheque algumas de suas

\footnotetext{
45 Essa questão fíca explícita no conto "Saímos das jaulas" (p. 131-134), em que é conferida uma condição animalesca a um grupo de homens negros famintos que disputam entre si a carcaça de um cavalo morto, com o objetivo de se alimentarem dela.

${ }^{46}$ Para reforçar a ideia de que não deseja nutrir sentimentos como o amor ou a paixão, ele diz, sobre Margarita: "Trepamos um pouco. Fazia três dias que não a via. Eu gosto dessa negra. Principalmente quando fica um pouco em silêncio. Ela fala bobagem e tenta ser simpática até dizer chega, e isso cansa. De qualquer forma, é só atração sexual. Só isso. Pra mim é suficiente. Fiquei com o coração empedrado, sou incapaz de sentir por uma mulher algo mais que uma ereção" (GUTIÉRREZ, 2008, p. 205). Aparentemente o protagonista compreende a figura feminina mais como um objeto para lhe proporcionar prazer sexual do que como um ser humano integral, dotado de corpo físico, emocional e intelecto.
}$$
\text { GANPHLAC }
$$

Revista Eletrônica da ANPHLAC, ISSN 1679-1061, N. 17, p. 139-168, jul./dez. 2014. http://revista.anphlac.org.br/ 
construções sobre a masculinidade do homem cubano. A crítica literária e jornalista Diana Sarabia (2012, p. 35) chama a atenção para as passagens da narrativa em que pode-se considerar que o próprio protagonista tem a sua condição de "macho tropical" ridicularizada, o que, segundo sua ótica, constitui-se como uma crítica à dinâmica das relações de gênero na sociedade cubana.

Tais tensões sobre a imagem da personagem podem ser interpretados quando Pedro Juan leva uma surra de uma mulher, que o deixa desacordado (GUTIÉRREZ, 2008, p. 54-55), e ouve de Martica que ela era lésbica e que, para sentir prazer enquanto mantinham relações sexuais, ela precisava pensar em alguma mulher (GUTIÉRREZ, 2008, p. 74-75), e quando Pedro Juan leva Luisa, a mulher com quem morava, para se prostituir, ou na situação posterior, em que ele próprio decide prostituir-se.

Pedro Juan expressa da seguinte maneira a situação em que se tornou um proxeneta:

A crise arrasava tudo. Ficamos algum tempo passando fome e muito fodidos, até que cansei de tanta miséria e tomei uma decisão. Uma tarde peguei Luisa na marra e disse: "Olha, chega de ficar de braços cruzados e passando fome. Vai pro Malecón, fazer a vida!” E foi uma boa decisão. Tem semanas em que essa mulata ganha até trezentos dólares. Pronto. Dane-se a miséria! (GUTIÉRREZ, 2008, p. 194)

Portanto, o jineterismo apresenta-se na narrativa como uma alternativa econômica frente à miséria vivenciada no Período Especial. Inclusive, o modo como narra essa passagem revela uma das principais características da personalidade do protagonista: o cinismo. ${ }^{47}$ Para Pedro Juan, era irrelevante o meio pelo qual a miséria foi burlada, importava somente o seu fim. Ele não se preocupa com o fato de Luisa relacionar-se sexualmente com outros homens, mas sim com a condição de estar recebendo dólares por isso. O que poderia ser uma possível afronta ao perfil de masculinidade de um "macho tropical e visceral" é classificado como "uma boa decisão". E, na verdade, como Pedro Juan obrigou-a a se prostituir ("Uma tarde peguei Luisa na marra"), fica evidente o seu sentimento de posse sobre essa mulher.

\footnotetext{
${ }^{47}$ A respeito dessa característica, o próprio Pedro Juan declara: "Nunca entendi bem todos esses valores éticos cheios de direitos e deveres. Sou um cínico. Assim é mais fácil. Pelo menos para mim é mais fácil”. (GUTIÉRREZ, 2008, p. 22)
}

\section{GANPLAC}

Revista Eletrônica da ANPHLAC, ISSN 1679-1061, N. 17, p. 139-168, jul./dez. 2014. http://revista.anphlac.org.br/ 
A respeito do fenômeno de homens que passaram a agenciar as próprias esposas no mercado do sexo durante o Período Especial em Cuba, a antropóloga Isabel Holgado (2002, p. 262-263) afirma:

Por su parte, los hombres que comercian con la capacidad sexual de estas muchachas muestran el fuerte arraigo del sentimiento de propiedad respecto a sus mujeres. El chulo-esposo, celoso recalcitrante ante cualquier desmán de su hembra e inquisidor de todos sus movimientos, no siente celos ante la oferta-venta de su jeba, precisamente porque es $s u$ jeba, su posesión-mercancía. Mientras deben defenderlas de la codicia de los machos cubanos, los clientes extranjeros no son rivales para los esposos de las jineteras. El beneficio económico es un matiz que, automáticamente, modifica su valoración.

É esta a perspectiva que fundamenta a ação de Pedro Juan: para ele, Luisa representa sua "propriedade-mercadoria", como uma mulher que, além de obedecer-lhe, precisa the proporcionar lucro. Mas além de impor que a companheira se prostituísse, Pedro Juan também se dedicou a esse oficio. Outra demonstração do cinismo do protagonista é o modo como narra a forma como ele próprio passou a prostituir-se: "me dediquei a uma atividade um pouco mais fácil e que dá mais dinheiro. Fui ser michê. Mas com as velhas. As turistas. Não tenho paciência para veado. Sério. Fico violento e me dá vontade de baixar a porrada" (GUTIÉRREZ, 2008, p. 216). Pedro Juan declara-se como um verdadeiro "artista" por conseguir se relacionar sexualmente com mulheres idosas.

Mas, por este motivo, o personagem foi preso e passou dois anos e meio na prisão. Caso fosse preso novamente em reincidência, seria condenado a dez anos de reclusão, situação que satiriza: "Portanto as senhoras vão perder o melhor suvenir de Cuba. Não tem jeito. É a vida" (GUTIÉRREZ, 2008, p. 218). Ou seja, não existem conflitos morais a esse respeito. Até porque, para além do sarcasmo, como homem inserido em uma sociedade que glorifica os códigos de masculinidade hegemônica, sua atuação exalta a representação de um "super macho tropical", que se relaciona até mesmo com mulheres pouco atrativas por estarem "muito deterioradas pelo tempo" (GUTIÉRREZ, 2008, p. 216).

\section{CANPHLAC}

Revista Eletrônica da ANPHLAC, ISSN 1679-1061, N. 17, p. 139-168, jul./dez. 2014.

http://revista.anphlac.org.br/ 
Dessa forma, o autor evidencia na narrativa que a experiência da crise econômica no Período Especial, além de motivar a ampliação da noção de práticas possíveis de se empreender para assegurar a subsistência, incluindo atuações não consideradas anteriormente, também desestabilizou e alargou os valores morais vigentes nessa sociedade.

\section{Considerações finais}

A crise do Período Especial se desenha em três níveis na narrativa de Gutiérrez: a crise econômica, a crise de valores e a crise existencial. Por meio desses diferentes âmbitos, o autor confere maior amplitude às noções acerca dos impactos da crise, se distanciando do conteúdo presente no discurso oficial ao considerar mais do que a conjuntura econômica e os aspectos materiais.

No tocante à edificação de paradoxos, característica relevante para a articulação da narrativa e composição da personalidade "cínica" de Pedro Juan, defendo a hipótese de que, mais do que desestabilizar a figura do "macho", como argumenta Sarabia (2012), esse recurso traça correlações com as contradições presentes no imaginario social. Nesse sentido, acredito que quando o protagonista se define racialmente de modo distinto em diferentes contextos, tanto como branco, assim como mulato; ou nos momentos em que constrói discursos impregnados de expressões racistas e sexistas, da mesma forma que critica a mesma perspectiva pronunciada por terceiros, evidencia a intencionalidade de sublinhar a existência de amplas tensões, ambivalências e conflitos no cerne do discurso e das práticas do próprio Estado cubano.

É possível que o autor busque apontar com isso que as contradições não se restringem apenas à vida do protagonista Pedro Juan, elas são inerentes à sociedade cubana como um todo e estão vinculadas inclusive, à administração do governo socialista. Dessa forma, seria possível identificar a formulação de uma analogia entre o caráter do protagonista da obra e o perfil do Estado cubano. Considero que Gutiérrez busca evidenciar as tensões sociais acentuadas no cenário da crise do Período Especial, mas, de modo indireto, traça críticas à fragilidade dos mitos e à falta de autocrítica dos dirigentes do governo revolucionário.

\section{GANPHLAC}

Revista Eletrônica da ANPHLAC, ISSN 1679-1061, N. 17, p. 139-168, jul./dez. 2014. http://revista.anphlac.org.br/ 


\section{Referências documentais e bibliográficas}

AGUILAR, Carolina; POPOWSKI, Perla; VERDESES, Mercedes. Mujer, período especial y vida cotidiana. Temas, n. 5, p. 11-17, 1996.

ALCÁZAR, Ana Campos. Turismo sexual, jineterismo, turismo de romance. Fronteras difusas en la interación con el otro en Cuba. Gazeta de Antropología, n. 25/1 - 2009, p.1-18.

Disponível em: http://www.ugr.es/ pwlac/G25_16Ana_Alcazar_Campos.pdfAcesso: abr/2012.

ÁLVAREZ, Inmaculada. El discurso sexual como valor de identidad nacional de lo cubano. Revista de Humanidades, Monterrey, n. 14, p. 13-35, 2003.

AYERBE, Luis Fernando. A revolução cubana. São Paulo: Editora da UNESP, 2004.

BEHAR, Sonia. La caída del hombre nuevo. Narrativa cubana del periodo especial. Miami: Florida Internacional Universit, 2007.

BIRKENMAIER, Anke. El realismo sucio en América Latina. Reflexiones a partir de Pedro Juan Gutiérrez. Disponível em: http://www.pedrojuangutierrez.com/Ensayos_ensayos_Anke\%20Birkenmaier.htm Acesso em: jun. 2012.

BOBES, Velia Cecilia. Las mujeres cubanas ante el período especial: ajustes y cambios. Debate Feminista, México DF., v.12, n. 23, p. 67-96, 2001.

- Participación vs. identidad: Mujeres en el espacio público cubano. Perfiles Latinoamericanos, México (DF), n. 15, p. 99-118, 1999.

CASAMAYOR, Odette Cisneros. ¿Cómo vivir las ruinas habaneras de los años noventa?: Respuestas disímiles desde la isla en las obras de Abilio Estévez, Pedro Juan Gutiérrez y Ena Lucía Portela. Caribbean Studies, San Juan, año/vol. 32, n. 2, p. 63103, 2004.

CASTRO, Fidel Ruz. Discurso pronunciado por Fidel Castro Ruz, presidente de la República de Cuba, en la clausura del XVI Congreso CTC, celebrado en el Teatro "Carlos Marx” el 28 de enero de 1990, "Año 32 de la Revolución”. Disponível em: www.cuba.cu/gobierno/discursos/1990/esp/f280190e.html Acesso em: out. 2011.

\section{CANPHLAC}

Revista Eletrônica da ANPHLAC, ISSN 1679-1061, № . 17, p. 139-168, jul./dez. 2014. http://revista.anphlac.org.br/ 
Mujeres y revolución. Habana: Editorial de la Mujer, 2006.

O homem novo e a nova mulher em Cuba. São Paulo: Global, 1979.

CHARTIER, Roger. À beira da falésia. A história entre certezas e inquietude. Porto Alegre: Editora da UFRGS, 2002.

. A história cultural: entre práticas e representações. Lisboa: Difel, 1988.

COELHO, Paula Carvalho; TREVISAN, Ana Lucia. O efeito do real em Trilogia suja de Havana, de Pedro Juan Gutiérrez. Universidade Presbiteriana Mackenzie, VII Jornada de Iniciação Científica - 2011. Disponível em: www.mackenzie.com.br/fileadmin/Pesquisa/pibic/publicacoes/2011/pdf/let/paula_de_ca rvalho.pdf Acesso em: jul/2012.

DE LA FUENTE, Alejandro. Una nación para todos. Raza, desigualdad y política en Cuba 1900-2000. Madrid: Editorial Colibrí, 2001.

ELIZALDE, Rosa Miriam. Flores desechables ¿Prostitución en Cuba? La Habana: Abril, 1996.

ESCOBAR, Reynaldo. Los ángeles perdidos. Revista Encuentro de la Cultura Cubana, Madrid, n. 4/5, p. 65-67, 1997.

FELIPE, María Teresa Fernández; VÁLDES, Edith Duyos. La crisis y el ajuste cubano en los 90: apuntes en torno a lo social. Perfiles Latinoamericanos, México, D. F., n. 8, enero/junio, p. 97-114, 1996.

GONZÁLEZ-ABELLÁS, Miguel. El problema del yo: Autor y narrador en la ficción cubana reciente. (2005) Disponível em: http://pendientedemigracion.ucm.es/info/especulo/numero29/probleyo.html Acesso em: $\mathrm{mai} / 2012$.

GOTT, Richard. Cuba. Uma nova história. Rio de Janeiro: Jorge Zahar, 2006.

GUEVARA, Che. Socialismo e juventude. Textos e fotos. São Paulo: Anita Garibaldi, 2005.

GUILLARD, Norma. La mujer negra, su representación gráfica y los estereotipos en la publicidad. Revista Panorama da Realidade Cubana: UNB, v. II, 2004. Disponível em: <http://vsites.unb.br/ceam/nescuba/artigos/pano221.htm> Acesso em: 7 fev. 2006.

GUTIÉRREZ, Pedro Juan. Animal/ tropical.São Paulo: Companhia das Letras, 2002. Nosso GG em Havana. Rio de Janeiro: Alfaguara, 2008.

\section{CANPHLAC}

Revista Eletrônica da ANPHLAC, ISSN 1679-1061, N. 17, p. 139-168, jul./dez. 2014. http://revista.anphlac.org.br/ 
O insaciável homem-aranha. São Paulo: Companhia das Letras, 2004.

. O ninho da serpente: Memórias do filho do sorveteiro. São Paulo: Companhia das Letras, 2005.

O rei de Havana. São Paulo: Companhia das Letras, 2001.

Trilogia suja de Havana. São Paulo: Alfaguara Brasil, 2008.

HAVRANEK, Alice. Cuba na atualidade: o impasse e o silêncio. In: COGGIOLA, O. (Org). Revolução cubana. Histórias e problemas atuais. São Paulo: Xamã, 1998. p.155167.

HOLGADO, Isabel Fernández. ¡No es fácil! Mujeres cubanas y la crisis revolucionaria. Barcelona: Icaria, 2002.

MARQUÉZ, Dionisio Arreaza. Escritura, economia y sexualidad en Trilogia sucia de La Habana de Pedro Juan Gutiérrez. (2007) Disponível: http://www.pedrojuangutierrez.com/Ensayos_ensayos_Dionisio-Marquez-Arreaza.htm Acesso em: jun. 2012.

MESA-LAGO, Carmelo. A economia cubana no início do século XXI: avaliação do desempenho e debate sobre o futuro. Opinião Pública, Campinas, v. IX, n. 1, p. 190223, 2003.

Problemas sociales y económicos en Cuba durante la crisis y la recuperación. Revista de la Cepal, Santiago de Chile, n. 86, p. 183-205, 2005.

MISKULIN, Silvia César.Os intelectuais cubanos e a política cultural da Revolução 1961-1975. São Paulo: Alameda, 2009.

MOLYNEUX, Maxine. Movimientos de mujeres en América Latina. Estudio teórico comparado. Madrid: Ediciones Cátedra, 2003.

OLONDO, Almudena. Economía sumergida, prosttución emergente. In: OCHOA, Maria Luisa Fernandéz. ¡Ay, qué rico! El sexo en la cultura y la literatura cubana. $2^{\mathrm{a}}$ edición. Valencia: Advana Vieja, 2006, p. 147-168.

PERICÁS, Luis Bernardo. Che Guevara e o homem novo. In: COGGIOLA, O. (Org). Revolução cubana. Histórias e problemas atuais. São Paulo: Xamã, 1998, p. 95-111.

PESAVENTO, Sandra Jatahy. Em busca de uma outra história: imaginando o imaginário. Revista Brasileira de História, São Paulo: ANPUH; Contexto, v. 15, n. 29, p. 9-27, 1995.

\section{GANPHLAC}

Revista Eletrônica da ANPHLAC, ISSN 1679-1061, N. 17, p. 139-168, jul./dez. 2014.

http://revista.anphlac.org.br/ 
História e história cultural. 2.ed. Belo Horizonte: Autentica, 2008.

RODRÍGUES, Pablo Ruiz. Los marginales de las alturas del mirador. Un estudio de caso. La Habana: Fundación Fernando Ortiz, 2011.

ROJAS, Rafael. El estante vacío. Literatura y política en Cuba. Barcelona: Anagrama, 2009.

SAN MARTÍN, Araceli Moreno. Un mito posible: La prostitución ilustrada. In: OCHOA, Maria Luisa Fernandéz. ¡Ay, qué rico! El sexo en la cultura y la literatura cubana. Valencia: Advana Vieja, 2006, p. 171-183.

SARABIA, Diana. Trilogía sucia de La Habana (1998) de Pedro Juan Gutiérrez: Reafirmación y transgresión de identidades de género en Cuba revolucionaria. Disponível em: http://aix1.uottawa.ca/ gsamll/GSAMLL/paginas/laverdolaga1.pdf Acesso em: jul/2012.

SIERRA, Abel Madero. Del otro lado del espejo. La sexualidad en la construcción de la nación cubana. La Habana: Casa de las Américas, 2006.

VILlAÇA, Mariana. Cinema cubano. Revolução e política cultural. São Paulo: Alameda, 2010.

\section{GANPHLAC}

Revista Eletrônica da ANPHLAC, ISSN 1679-1061, N. 17, p. 139-168, jul./dez. 2014.

http://revista.anphlac.org.br/ 